\title{
Capital x Labor in the Creative Industries: A Marxist Approach to Copyright and Related Rights
}

\section{Capital x Trabalho nas Indústrias Criativas: Uma Abordagem Marxista para Direitos Autorais e Direitos Relacionados}

\author{
Nayara Albrecht, University of Brasilia
}

\begin{abstract}
This paper aims to develop an alternative framework to understand copyright based upon a Marxist analysis of this field. By providing a bibliographical research on both the fundamentals of property theories and Marxist perspectives, I try to promote another understanding on how creative industries operate. Therefore, the paper provides a literature study on both intellectual property theories and Marxism. Regarding intellectual property theories, I focus on four types of approaches: welfare theory, labor theory, personality theory and culture theory. In what concerns Marxist perspectives, I explain most fundamental concepts such as "class", "exploitation" and the relationship between classes and State according to a Marxist view. Then, I try to build a framework that links these concepts. Finally, I employ this Marxist framework to the "modus operandi" of copyright core industries by analyzing how stakeholders interact with each other and in what extent they may affect public policies on copyright and related rights. In the final remarks, I suggest a research agenda on Marxism and copyright. Thus, this is a preliminary exercise to encourage other studies.
\end{abstract}

Keywords-Copyright, Marxism, Politics.

Resumo-Este artigo tem como objetivo desenvolver uma estrutura alternativa para entender os direitos de autor com base na análise marxista desta área. Ao fornecer uma pesquisa bibliográfica sobre os fundamentos das teorias da propriedade e as perspetivas marxistas, tenta-se promover um outro entendimento sobre como as indústrias criativas operam. Portanto, o artigo fornece um estudo de literatura sobre teorias de propriedade intelectual e marxismo. Em relação às teorias de propriedade intelectual, concentro-me em quatro tipos de abordagens: teoria do bem-estar, teoria do trabalho, teoria da personalidade e teoria da cultura. No que concerne às perspetivas marxistas, explicam-se os conceitos fundamentais como "classe", "exploração" e a relação entre classes e Estado, de acordo com a visão marxista. Deste modo, constrói-se um framework que conecte estes conceitos. Por fim, emprega-se essa estrutura marxista no "modus operandi" das indústrias centrais de direitos de autor, analisando como as partes interessadas interagem umas com as outras e em que medida elas podem afetar as políticas públicas sobre direitos de autor e direitos relacionados. Nas considerações finais, sugere-se uma agenda de pesquisa sobre marxismo e direitos de autor. Este é um exercício preliminar para encorajar outros estudos.

Palavras-Chave-Direitos de Autor, Marxismo, Políticas.

Submitted-17-11-2016. Accepted-30-05-2017.

- Nayara Albrecht, Ph.D. student in Political Science at the University of Brasilia.

E-mail:nayaramcd@gmail.com 


\section{Introduction}

$\mathrm{O}$ NE of the main justifications for protecting copyright and related rights relies upon the recognition of the role authors and performers portray in the cultural life. Based upon a utilitarian perspective, the concession of exclusive rights to creators aims to promote culture by generating incentives for them to create intellectual works (c.f. Fisher 2001) ${ }^{1}$. Not surprisingly, most justifications for Intellectual Property (IP) rights have the notion of "public interest", through either this utilitarian view or some perspective more concerned with access to culture. Copyright and related rights protect a varied range of materials, e.g., motion pictures, music and books, which are essential to achieve economic, social and cultural goals.

Thus, despite the private nature of license agreements, copyright and related rights are closely akin to the public interest. This happens due to their impacts on access to information, education and culture. Nonetheless, as other property rights, it is a field in which there is no unanimous political view. One of the main reasons for the lack of consensus is the multitude of stakeholders involved in issues regarding copyright and related rights. Authors, performers, publishers, record labels, collective management organizations and, most recently, digital platforms, all of them play a role in developing public policies regarding copyright protection. All of them have their own interests, either increasing or diminishing the scope of protection. Consequently, all of them try to reach the government in order to "get what they want".

This article aims to provide a theoretical framework capable of analyzing the attempts of these stakeholders in affecting government decisions through lobbying. To this purpose, I try to develop a Marxist approach to copyright fundamentals in order to analyze its inherent political disputes. It is an effort of theorizing political actions of copyright core industries on political science grounds, but it is also an exercise of applying Marxist concepts to the rationale of copyright.

DOI:http://dx.doi.org/10.21814/perspectivas.78

1 . This perspective is more common in countries following the common law tradition.
In fact, I claim political science has much to offer to the field of copyright and related rights.

First of all, political science provides philosophical grounds to many intellectual property theories. It is possible to assume there are four main theories on intellectual property: welfare theory, labor theory, personality theory and culture theory (Fisher 2001). Each one represents different types of justifications for IP rights centered on either a kind of natural right or the concept of economic incentives (I try to exam these theories in more detail in further sections of this paper). In any case, all these theories draw on the writings of authors from political philosophy, such as John Locke, Emmanuel Kant and Friedrich Hegel.

Secondly, it is important to remember that copyright and related rights are part of a field subject to many policy processes. In this sense, political science provides many theories trying to explain policy changes. These theories may be used to analyze the field of copyright and related rights too, as some authors already did (cf. Herman 2009). Finally, political science may offer important tools to analyze political conflicts, such as theories regarding collective action and interaction repertories. Debates on copyright presuppose a broader analysis about disputes and political actions of different groups and individuals.

One may ask what role Marxism plays in this field after all. The answer is simple: by developing a systematization of the concepts of "property" and "class", Marxism may provide important tools to analyze disputes concerning copyright and related rights. These disputes involve distinct stakeholders with different political views, since content industries, technology corporations and end users are largely affected by public policies on copyright.

Thus, it is possible to build a theoretical framework based on Marxism to study the relationship between these stakeholders. This is what I tried to do in this paper: to discuss how Marxism would frame the political disputes inherent to copyright, especially in what regards interactions between the agents according to their positions in the economic structure. It is a primary theoretical exercise, since there are few studies linking 
Marxism to copyright ${ }^{2}$ and most of them focus on specific issues, such as technology or information society (for an example, see Söderberg 2002). This paper gives more attention to the political process and its consequent impacts in copyright legislation on philosophical, economic and political grounds.

Instead of centering in some specific aspect, such as technology, I try to introduce a general framework. The paper presents a literature study on intellectual property theories and Marxist approaches. I do not try to give a full explanation of Marxism, since it is a complex and heterogeneous stream of political thought. Instead, I try to highlight Marxist concepts that can be useful to understand traditional rationales for copyright protection.

The structure of the paper is divided into three topics, besides introduction and final remarks. The first topic, "main theories of intellectual property", brings an overview on intellectual property theories in order to make readers understand the basic rationale of copyright and related rights. The second topic, "some fundamentals of Marxism", discusses the main Marxist concepts. The third one shows how it is possible to use Marxism to analyze political disputes involving copyright and related rights. Often there are many studies on the economic impact of copyright-base industries ${ }^{3}$. Now, it is time to analyze their political impact. Marxism provides a useful set of methods and concepts to do that.

\section{Main Theories of Intellectual Prop- erty}

Theories of Intellectual Property comprise beliefs and arguments that justify intellectual property rights. In general, they may be divided into four types of approaches (Fisher 2001). The first one, which Fisher (2001) calls "utilitarian view" or "welfare theory", is related to the concept of "incentives". According to this perspective, lawmakers must try to pursuit the maximization of net

2. There are some interesting articles on labor and creative industries though (see Rossiter 2003, Lee 2013).

3. As an example, I can mention the studies from the World Intellectual Property Organization (WIPO): http://www.wipo. int/copyright/en/performance/ (last accessed December 2016). social welfare (Fisher 2001). In this sense, the law must provide an economic incentive to shape the behavior of individuals in order to have a specific outcome (in this case, the "maximization of net social welfare"). Copyright protection is the main tool for providing this economic incentive.

The goal is to achieve a balance between the power of exclusive rights, which are justifiable to stimulate creativity, and the public enjoyment of creations. In this sense, the exclusive rights would represent an economic incentive to artists for producing new works (Fisher 2001; Landes and Posner, 1989). The justification for this type of incentives is based on the view of human beings as rational agents: being rational, the individual pursues the maximization of his or her happiness; by attempting to receive greater amounts of money from copyrights' royalties, he or she is encouraged to produce more works; by producing more works, he or she contributes to society as a whole (Fisher 2001).

Thus, utilitarian theories serve to justify the monopoly represented by exclusive rights. In this sense, a limited monopoly is necessary in order to foster creativity (Menell 2000). The necessity of providing a monopoly results from the "public good" nature of intellectual goods (Landes and Posner 1989). This "public good" aspect refers to the fact that intellectual goods are non-rival and non-excludable by nature, which means that people can usually copy books and other copyrighted material with little additional effort (Boyle 2008). In other words, the cost of creating such a type of intellectual good is still high in comparison with the little cost of reproducing the work and making it accessible to a larger public (see Landes and Posner 1989).

Accordingly, exclusive rights - the power of creator in preventing others to make copies aim to increase the creator's total revenues to incentivize him or her to create works (Landes and Posner 1989). Thus, the desired outcome is not individual, but collective. Similarly, the second approach - the "labor theory" (or "fairness theory") - also sees copyright protection as a way to compensate creators, but the focus is not to provide incentives, for its central problem is based on a conception of copyright and related rights as natural rights. 
Differently from utilitarianism, the second approach focuses on the idea of fairness. Based on the writings of John Locke, this perspective assumes that the person who labors has a natural right to the fruits of his/her efforts (Fisher 2001). Thus, it draws upon the idea of justice as a matter of rewarding creators for their contribution. Despite its focus on the individual, it cannot be affirmed that this theory neglects the importance of the public interest either. Locke pays a special attention to the "commons". Indeed, in Lockean theory, the natural right is valid when the person mixes his/her labor to nature, transforming it into something of his/her own (Menell 2000). Thus, intellectual property rights are justified only if the person gives his/her own contribution to the commons.

Locke also establishes three provisos (sufficiency, spoilage and duty of charity), which are limitations to property rights (Fisher 2001). These three provisos establish some restrictions to the freedom of individuals to mix their labor with the land. According to the sufficiency and the spoilage provisos, individuals are free to make improvements in the nature as much as it does not spoil and there is sufficient and good land ${ }^{4}$ left for others. In this sense, property rights are necessary to protect the commons by rewarding individuals who make optimal use of resources (Hull 2009) ${ }^{5}$ and they may be granted only under certain conditions.

Therefore, there are two possible interpretations to Locke's property theory: a normative interpretation more akin to a moral justification of property rights and an instrumentalist interpretation that emphasizes the goals of rewarding creators to make them work hard. Whereas the normative interpretation establishes "labor must be rewarded" (Hughes 1988) as a matter of justice, the instrumentalist interpretation says labor must be rewarded in order to motivate people to perform labor. The latter is closer to the utilitarian

4. Locke's theory was designed for physical property (land) at first, but it can be applied to intellectual property as well.

5. There are some criticisms to this interpretation of Locke's provisos (see Narveson 1999). In fact, there are many possibilities of interpreting Locke's provisos. Here I try to focus on two of them: one with a utilitarian ground and other closer to a moral justification of property rights. approach as labor is deemed pertinent to the promotion of the public good (see Hughes 1988).

A strong alternative to Locke's labor theory is the so-called "personality theory" (Hughes 1988). Inspired by the works of Kant and Hegel, this perspective is centered on the question of fundamental human needs. Bearing in mind the importance of creativity and intellectual activity to human flourishing, property rights serve human needs. Intellectual products are seen as manifestations or extensions of personalities of their creators, which justifies a "right of self-expression". Prominent in Europe, this theory provides support for moral rights, defined by authors' and artists' rights to control the public disclosure of their works, to withdraw their works from public circulation, to receive appropriate credit for their creations, and above all to protect their works against mutilation or destruction (Fisher 2001: 9).

As Hughes (1988: 28) claims, "such a justification posits that property provides a unique or especially suitable mechanism for self-actualization, for personal expression, and for dignity and recognition as an individual person". Property rights are means to guarantee that persons will have access to resources deemed necessary to achieve their goals of self-development (Hughes 1988). According to this perspective, the benefits of property rights aim the individual instead of collectivity.

On the other hand, the last approach relates copyright to the purpose of fostering the achievement of a just and attractive culture. Consequently, it argues that social and political institutions must be organized to facilitate the flourishing of human nature, which is mysterious and complex (Fisher 2001). Inspired by a varied range of authors, this philosophical perspective focuses on the development of culture instead of rewarding authors and artists.

As we can see, most justifications for copyright have some elements related to the protection of the public interest. Even the labor theory, which focuses on the individual labor, brings some limitations to property rights. Although some theories emphasize personal or individual benefits, property rights always serve to some moral purpose instead of being an end in itself.

Although these justifications are theoretical 
discussions, it is possible to use their arguments to analyze realities of many different countries. The first Statute on copyright, the Statute of Anne (England 1710), for instance, evoked the words "Encouragement of Learning" as the purpose of granting "copy rights". Similarly, the Constitution of the United States mentions the promotion of the progress of science and useful arts. Utilitarianism has been particularly important in the US as the Congressional Committee reporting on the 1909 Copyright Act stated copyright is based upon the welfare of the public (Menell 2000).

In contrast, continental Europe, marked by a system of "droit d'auteur", highlights the ties between the creator and her/his work. In this perspective, copyright is a natural right of the person who creates the works. It is related to human development and to "being a person". As the work is deemed to be a part of the person or of the self, this theory justifies the enforcement of moral rights (Menell 2000), which are predominant in Europe in contrast with the United States. This perspective is also found in some countries of Latin America, such as Brazil. In some cases, more than one intellectual property theory appears as different justifications for copyright protection emerge in governmental decisions and case law.

Therefore, theoretically copyright exists to achieve some specific goals: creating incentives for authors to provide new cultural goods; rewarding creators for their efforts or labor; protecting the personality of the artist; or fostering an attractive culture. This means that copyright protection is not an end in itself, but an instrument to achieve something. In most theories, this "something" is related to some public goal. In addition, the theoretical backgrounds of intellectual property protection focus on human beings, especially primary right holders and end users, not on enterprises or corporations.

\section{Some Fundamentals of Marxism}

Marxism is not a homogeneous stream of political thought, since it comprises many revisionist followers of Marx. However, I argue that there is a "backbone" congregating Marxist authors. Marxism represents a set of philosophical and political ideas based on some key concepts, as "property", "class" and "State". In this paper, I will analyze more deeply the first two, although the concept of "class" brings some implications to the ways authors discuss the relationship between class and State. This is also a relevant aspect for understanding any political dispute, including those ones related to copyright and related rights.

In orthodox Marxism, property refers to ownership relations. Marx (2007 [1848], 1970 [1865], 1981 [1875]) does not criticize all types of property, but a special one: the bourgeois property, usually called "private property". The negative judgment on private property rights comes from Marx's ideas on exploitation. Despite differences among followers of Marx, the central notion of both concepts of "property" and "class" is the idea of exploitation. Usually we can divide Marxists into two conceptions of "class": a perspective centered in the historical process (consequently called here "historical perspective") and a "static" perspective. Differences between these two views is perceptible in the work of Thompson (1978).

By studying the eighteenth-century English society, E.P. Thompson (1978) analyzed how the usage of certain terms, such as "preindustrial" and "paternalism", hides the differences between modes of production and, consequently, the differences between slaves and free labor. Since paternalism is used to describe a non-conflictive relationship between plebe and gentry, authors associate it to a past experience in contrast with the competitive individualism of the "natural man of young capitalism" (Thompson 1978: 137).

The concept of "class" adopted by Thompson (1978) refers to a historical category in opposition to another concept of "class" which the author considers "static". A historical concept of class means the category emerges from the observation of a social process during a certain time. Structures and models are developed theoretically to offer objective determinants of class, for instance, expressions of different productive relations. Thompson claims the historical perspective is the proper usage of the concept of "class" as exposed by mainstream Marxism.

Alternatively, static perspectives employ categories centered on the inertia of the concept. According to Thompson (1978), these perspectives are restricted to quantitative measures, e.g., sur- 
veys in which persons answer about which classes they belong. The static perspectives bring the idea of "false consciousness" for the reason that classes belong to a static model based on the capitalist productive relations. In the historical perspective, it is possible to employ the concept of "class" either as a real historical content or as a heuristic or analytical category to organize historical evidence with less direct correspondence.

Thus, in the case of the first sense, class is part of the cognitive system of people living in the period the researcher is studying. In the second case, the researcher may refer to periods before the industrial revolution, when class division was not part of the cognitive system of people. Accordingly, it is important to be careful with the usage of the term "class" in these periods, since the historical evidence available is much less direct. This second case corresponds to the analysis Thompson (1978) provides about the relationship between plebe and gentry in eighteenth-century England.

Still, as Thompson (1978) argues, concept of class may be used even for analyzing anachronic periods when there is no other adequate category to deal with the historical process (the common expression is not "clans fight", but specifically "class struggle"). According to its heuristic usage, class is inseparable from the notion of "class struggle", which is the primary and universal concept. In this sense, classes do not exist as separated entities, but in relation to a context of struggle: people are in a structured society, they live a context of exploitation (either as the exploited or as the exploiter), they identify their antagonistic interests and they found out that they are members of certain classes (Thompson 1978).

Differently from the static perspective, classconsciousness could not exist previously, but it would be a consequence of this process, i.e., class and class-consciousness are part of the last phase of the historical process. If we adopt a static perspective, classes pre-exist to the struggle (Thompson is against this logics). Therefore, according to Thompson (1978), class is a consequence from historical processes related to class struggle. A central element of class identity is the antagonism between classes.

In contrast with his view, there is a static per- spective that employs the term "class" in relation to the social structure, specifically the productive relations, instead of analyzing the historical process. In this sense, class positions result from property relationships (Miguel 1998). Erik Olin Wright (1997), for instance, shows that Marxist and Weberian traditions are convergent in the sense that both identify classes with relations between persons and economically relevant resources. Nonetheless, there is a difference of language: whereas the Marxist tradition deals with productive relations, the Weberian tradition refers to "market capacity".

According to Wright (1997), the Marxist tradition is more complete because it considers both the market capacity in the exchange relationships and the position in the productive relations. The class analysis implies understanding interconnections between its diverse elements: class formation (until classes become organized collective actors), class struggle (repertoires to achieve their goals) and class' consciousness (comprehension of one's own interests). Understanding the definition of "class structure" is important to discuss all these elements (Wright 1997). In order to understand class structure, it is necessary to analyze the concept of "exploitation".

The cornerstone of the Marxist conception on "exploitation" is the interdependence between material interests of agents in terms of their position in the productive relations (Wright 1997). Accordingly, Wright (1997) defines exploitation by three main criteria: the inverse interdependent principle, the exclusion principle and the appropriation principle. In sum, exploitation means that the material welfare of a certain group depends on the material deprivation of the other with an asymmetric exclusion of the exploited through appropriation of the fruits of their labor by those who exploits (i.e., those who control the resources). According to Wright (1997), exploitation occurs when these three principles are found; otherwise, we could frame them as other types of oppression.

A central aspect of exploitation in comparison with other types of oppression is that the exploiter needs the efforts of the exploited. Thus, there is a relationship of dependence, in which the exploiter needs to be moderate in order to have the consent 
of the exploited and to obtain a certain level of cooperation. This gives a certain degree of power to the exploited. Exploitation does not refer only to the status of social agents, but includes some pattern of a permanent interaction structured by social relations that mutually link the exploited to the exploiter (Wright 1997).

Exploitation is the basis of the antagonism between capitalists and workers generating a conflict of interests that involves not only questions regarding wages but also the amount of work efforts required by capitalists. In contrast to Thompson (1978), who analyzes class through historical processes, Wright (1997) divides classes according to exploitation and property relations. Therefore, even slave owners and slaves are framed as classes due to the property rights regarding slaves and the appropriation (by owners) of the fruits of their labor.

Although there are differences of approaches between Thompson (1978) and Wright (2015), they concentrate in one central point from Marxist theories: the conflict between classes. Both authors emphasize, to a certain extent, the antagonistic relationship between workers and capitalists. In the case of Thompson (1978), the conflict precedes even class origins and it refers to a historical process. In the analysis of Wright, the conflict results from the property relations, which are based on antagonistic interests. Exploitation and antagonistic interests play a key role in understanding copyright and related rights due to the relationship between the different stakeholders that act in this field.

\section{The Marxist Rationale and the "Modus Operandi" of the Creative In- dustries}

In general, the basilar concepts of class analysis are exploitation and antagonistic interests, discussed in the last section. Consequently, a central element in the Marxist tradition is class conflict and the relationship between workers and capitalists. These concepts are paramount to understand productive relations in creative industries ${ }^{6}$ due to its inherent "modus operandi". Copyright and related rights affect different types of stakeholders. By analyzing the policy space in the United States, Herman (2009) divides the stakeholders into two broad coalitions: "strong copyright", composed by agents who defend a stronger copyright protection and "strong fair use", composed by those who defend more flexibilities on copyright law.

There are at least five types of stakeholders directly affected by policies regarding copyright and related rights:

1) Authors, performers and musicians (primary right holders): they are the persons who create the works or participate in the performances. Authors are entitled to copyright and performers to related rights.

2) Publishers and record labels (secondary right holders): they are secondary right holders since they acquire the rights from primary right holders.

3) Collective management organizations: usually non-profit organizations, they act upon a type of mandate to represent right holders (primary and secondary) in order to collect and distribute royalties.

4) Services, platforms, digital stores exploiting economically protected content (large-sized users): here, the term "user" refers to companies or other types of entities that use artistic, literary or scientific works to obtain profits by providing these materials to the public. It is the case of Spotify, Deezer and Netflix.

5) End users: I use the term "end user" to refer to consumers or, broadly, individuals who access protected content

6 . There is no consensus about the meaning of the term "creative industries", and it is usually employed to differentiate it from the cultural industries (see Pires 2012, Dunlop and Galloway 2006). To simplify, I use the concept of UNESCO, which describes creative industries based on creativity and art (it includes cultural industries). More precisely, I use "creative industries" to speak about copyright core industries. Despite the criticisms, this concept is largely used by policymakers. I have chosen this expression because it is more akin to the economic dimension of culture. 
for self-enjoyment, usually for non-profit purposes.

The division between the two coalitions described by Herman (2009) - "strong copyright" and "strong fair use" - may be misleading because the relationships within these coalitions are complex. The relationship between the group represented by creators and artists (authors, performers and musicians) and the group composed by secondary right holders and representative organizations (publishers, record labels, collective management organizations) is controversial and full of conflicts. Marxism may help us to understand these disputes. What role Marxism portrays in this case? The answer is simple as it regards basic concepts from Marxism: "property", "capital", "labor" and "class".

Clearly, creators and performers are responsible for the productive labor. They act as the proletariat of the creative industries as they produce the intellectual goods (creations of the mind), i.e., creative, artistic and scientific works and performances. At the same time, they usually transfer their rights to secondary right holders, such as publishers and record labels. As license agreements represent a private contractual relationship, authors and performers negotiate their payments directly with secondary right holders.

It is plausible to claim that they have opposite interests: authors may want higher payments, whereas publishers and record labels want to pay lower prices in order to increase their profits. Bearing in mind the discussion in Wright (1997), I also claim that they are interdependent: publishers and record labels depend upon the work of authors and performers. Their profits come from the exploitation of intellectual works, which are creations of human mind provided by authors and performers $^{7}$. Therefore, while they try to increase their profits by lowering primary right holders' remuneration, they need some degree of moderation to have the consent of authors and performers, which refers to the interdependence described by Wright (1997).

7. Usually, in copyright language, performers are not deemed "creators"; they are entitled to related rights instead because they aid to promote artistic works. Nevertheless, I consider they "create" performances, giving their own individuality to these performances.
Exploitation becomes evident in the low remuneration of authors and performers. In most cases, authors and performers accept a low remuneration because they do not have means of promoting their own works. This is the reason why they need publishers and record labels. Accordingly, it is logical that publishers and record labels own the "means of production" insofar as they control the equipment to make intellectual works accessible to a larger public. Although copyrighted goods involve more than the economic aspect, economically it is useless if the author or performer create something they are not able to share with a larger public in exchange to some kind of remuneration. Thus, primary right holders have less bargaining power because they depend upon publishers and record labels to make profits from the uses of their works.

In many creative sectors, such as film, music and television, the employment relationships remain hierarchical and vertical with creative workers alienated from their intellectual property (see Rossiter 2003). In some sectors, the assignment of rights is even obligatory ${ }^{8}$. Against labor theory, secondary right holders are appropriating the fruits of the labor of others when they have the largest share of the payments.

Collective Management Organizations (CMOs) play a similar role in this context as these institutions, in many cases, represent the only possibility for authors and performers to get remuneration. Despite its relevance, there is a great deal of criticism about the lack of transparency and accountability in these institutions ${ }^{9}$ (see Vico 2015). Thus, whereas they

8. In the United States, for example, the rights of performers in motion pictures are assigned automatically to the producer (see Fisher 2004). In addition, some national legislations bring specific provisions to the employer-employee relations in terms of defining authorship of a work made under conditions of employment (the concept of "work-made-for-hire" in the US Copyright Act, for instance).

9. In Brazil, there were several meetings in the parliament to discuss the actions of the Central Bureau for Collection and Distribution (ECAD, in Portuguese), the main organization responsible for collecting and distributing copyright royalties in the music sector. ECAD has a monopolist situation provided for in the Copyright Act of Brazil. Despite the particularities of Brazil, criticism towards Collective Management Organizations (CMOs) is not an exclusive feature of that country. The European Union organized a study to re-exam the functioning of the CMOs. The study mentions the necessity to improve transparency. 
are necessary to make distribution and collection of royalties feasible, they may be also exploiting authors and end users by not providing enough information on the tariffs users must pay and the payments authors receive.

Therefore, it is clear that, in a Marxist framework, authors, performers and other "who produce" represent a type of proletariat, or labor class, due to the following factors:

1) They do not own the means of producing their creations in a large or massive scale ${ }^{10}$, which is important for getting a proper remuneration;

2) They have less bargaining power in comparison with large-sized companies;

3) They have more chances to be exploited by these companies.

Although remuneration is important to authors and creators, they also want recognition and fame, a type of symbolic capital in the words of Bourdieu (1986, 2011). In Bourdieu's field theory, the concept of "capital" refers to types of resources in terms of skill, knowledge or talent (O'Hara 2000), which are deemed necessary to have success in a specific field. In this sense, the world "field" means a social space with structured rules defined by the relation between the members of this virtual space (Bourdieu 1986, O'Hara, 2000). The symbolic capital refers to esteem and fame, whereas the economic capital is related to material accumulation (Bourdieu 1986, O'Hara 2000). Authors and creators look for both economic and symbolic capital and large-sized corporations aim at increasing their economic capital.

In many cases, authors and creators accept a low remuneration in exchange for greater diffusion of their works (there are some practical examples in O'Rourke 2003, and Hebb and Sheffer 2006). In this context, publishers and record labels represent the force of the economic capital against labor, in the Marxist sense, because their

10. One may argue that Internet changes this reality because it gives authors the possibility to promote their own works. Nevertheless, it also poses new challenges to remuneration, such as the appearance of new intermediaries, the lack of transparency of new business models and the difficulties related to controlling uses of intellectual works. For an outstanding overview on matters regarding technology and copyright, see Fisher (2004). primary goal is to increase their profits (material accumulation). They also own the means to produce and promote intellectual goods in a large scale. In most cases, primary right holders and secondary right holders have antagonistic and interdependent interests. Hence, it is easy to find where the conflict between Labor and Capital is in the creative industries: while publishers and record labels try to increase their profits, abusive contracts with low remuneration are responsible for the exploitation of authors and performers.

Usually, authors and performers are seen as part of the intellectual elite that comprises a small group of "those who contribute directly to the creation, transmission and criticism of ideas" (Bottomore 1966 [1964]: 70). They may be seen as members of the elite because they take part in some important political decisions as they have more visibility than other types of workers (including other workers in the creative industries). Nonetheless, it is a heterogeneous group, as it comprises people from different social backgrounds and with distinct political views (Bottomore 1966 [1964]). Consequently, it is a heterogeneous group in terms of the bargaining power of different members of the group. In this sense, it is important to bear in mind that a widely recognized artist has much more power than an independent one.

Here I identify authors and performers, in general, with the labor class because they have less power in comparison with publishers and record labels in questions regarding copyright and related rights. Nevertheless, their status and political impact vary and this heterogeneity must be considered. What matters most is their position in relation to ownership of means to promote intellectual goods and their relationship with other stakeholders.

The position of users is more difficult to place in the traditional Marxist framework as they have complex roles. Nonetheless, most recent Marxist approaches discuss the role of the middle classes, i.e., intermediate classes between the proletariat and the bourgeoisie. Users may be part of the middle classes due to their ambiguous position. They may try to exploit primary right holders by giving them less remuneration (by getting content freely, for instance), but they may also be exploited by second right holders. Whereas users 
may access illegal protected content without paying right holders, they may also be obliged to pay abusive prices to access some intellectual goods. Secondary right holders, such as publishers and record labels, are usually responsible for establishing these prices. This can be seen especially in the journal publishing industry, in which libraries face difficulties to pay subscription prices and the most recognized journals are concentrated in the hands of the same publishers (see McGuigan and Russell 2008, Larivière, Haustein and Mongeon 2015).

In addition, publishers in the academic publishing industry do not pay authors in many cases $^{11}$. Therefore, publishers and record labels have "income" and "authority", which would place them among capitalist in Wright's framework on social classes. In the case of intermediate users, such as services that economically exploit intellectual works, they do not own means to produce intellectual goods in large scale, but they are responsible for promoting this content to a public in exchange for money. Accordingly, they can also make high profits. Consequently, they have the "income", one of the elements discussed by Wright (1997).

Thus, I can see elements brought by both Thompson (1978) and Wright (1997) in conflicts regarding copyright and related rights. Moreover, it is possible to analyze the conflicts by the historical process that formed these classes. This is evident when we deal with intellectual property rights. The way intellectual property rights operate relates to history of different places. In countries with a common law tradition, there is a "copyright" system or "right to copy", in which the protection was granted originally to printers. In opposition, countries with civil law tradition have what is called "droit d'auteur", in which authors' rights are conceived as human rights (cf. Littoz-Monnet 2006). These systems are related to historical events - such as the French Revolution in the case of droit d'auteur.

Historical events also affect the formation of classes. At the same time, I can identify that some elements from the "static Marxist tradition", as income, authority and property relations are im-

11. Usually, authors assign their rights to publishers and lose the permission to distribute their own rights, as Rossiter (2003) explains. portant to define each class. Even considering the differences between Thompson and Wright, both approaches emphasize one central point to understand the field of copyright and related rights: the conflict between Labor (represented by authors, performers and others alike) and Capital (represented by big companies, mainly secondary right holders and sometimes large-sized users).

Although there are differences between principles from the traditions copyright and droit d'auteur, one may argue that intellectual property rights nowadays favor the secondary right holders to the detriment of both primary right holders and end users $^{12}$. In this sense, economic resources play a major role, as they affect the bargaining power of the different stakeholders in this field. This outcome is contradictory with the basilar principles of intellectual property, considering that almost every theory emphasizes the relevance of the public interest and the role of authors and creators to intellectual property rights. Instead, in practice, economic capital gains more and more space while secondary right holders try to make more money.

It does not mean that secondary right holders and intermediaries are not important; actually, they play an important role to promote intellectual works. Nevertheless, one may ask if the labor relationships between stakeholders are fair enough, especially considering the difficulties in measuring the value of the creative work of authors and performers. In addition, end users are also harmed because they are seen as potential infringers. In a digital era in which everybody wants to share content freely, every person may be subject to a lawsuit for copyright infringement, as national legislations do not allow any type

12. Whereas most international agreements provide a stronger protection for copyright, they do not provide artists and creators with specific tools to balance the bargaining power of secondary stakeholders. The European Union's proposal, within the Digital Market Strategy, has a provision that aims to improve right holders' position in negotiations (articles 10, 14 and 15 of the proposal for a directive in the Digital Single Market). On the other hand, the Marrakesh Treaty is the only international agreement that deals with user's rights, but it is focused on a specific group (people with physical and intellectual difficulties to access print materials). All treaties negotiated within the World Intellectual Property Organization (WIPO) are available on its webpage. 
of usage without the right holders' ${ }^{13}$ permission (except the limitations provided for in the law). Whereas the focus should be the economic exploitation of intellectual works, even non-profit uses are subject to penalties according to some national systems of copyright protection.

In other words, although they emphasize personal interests of author and creators as a particular feature of copyright and related rights, it is evident that the economic aspect became more important and it favors big companies and individuals with larger resources. In contrast with other intellectual property theories, a Marxist approach would claim property rights in the capitalist society originated to give still more economic resources to those who already own the means of diffusion intellectual goods. Constrains authors face and the consequent necessity to transfer their rights to secondary right holders allow social appropriation of their labor by big enterprises that do not participate directly in the creative process.

It is not surprising that copyright and capitalism are intrinsically related. Technological breakthroughs and market relations were necessary conditions to the emergence and expansion of copyright protection. Great Britain is a practical example, where the first advanced copyright law (the Statute of Anne) appeared as consequence of the emergence of the printing press. Although intellectual property theories highlight the role creators and performers portray, State used copyright protection in practice to control writings (Söderberg 2002). Since then, copyright protection has been increasing, as most international agreements deals only with protection and not with users' rights.

Regarding the political process that generates copyright legislation, those who gain concentrated benefits - the right holders - usually prevail in the detriment of the end users (Menell 2000). I claim there is also a difference among right holders, as some of them have more power, such as highly rec-

13. The Brazilian Copyright Law (Law n. 9610 of February 19, 1998) expressly forbids "any kind of use" of a literary, artistic or scientific work without the authorization of the right holder (article 29). There are few limitations and exceptions on article 46. The United States Code mentions that the copyright owner has the exclusive rights to authorize many kinds of use, such as reproduction and performance, independently of economic aspects. ognized artists and major record labels. A Marxist hypothesis about this difference of responsivity of State authorities would focus on the concepts of "permeability" (Poulantzas 2000 [1978]) and "selectivity" (Offe 1984 [1972]).

Although they deal with different subtopics, Nicos Poulantzas (2000 [1978]) and Claus Offe (1984 [1972]) approach the same subject: the privileged opportunities some groups have to access State institutions. Whereas Poulantzas analyzes the occupation of professional positions in State bureaucracy, Offe develops the concept of "structural dependency", which is related to the dependency of the State upon private capital.

According to Offe (1984 [1972]), the development of selectivity that serves to unify and protect a global capitalist interest is the main evidence of the classist dimension of the State. The structural dependency results from the concentration of investments by private entities, what results in State's decisions that do not oppose the interests of the capitalist classes. The dependency constrains the governmental agents. This is what Offe calls "selectivity of political institutions" (Miguel 2014), characterized by a coincidence between adopted policies and capitalist interests, including through opposition to the adoption of anti-capitalist politics.

On the other hand, Poulantzas (2000 [1978]) sees the politics of the State as a direct consequence from the contradictions of the State structure. Each part of the State represents a center of power of certain interests or a type of alliance. According to Poulantzas, the openness of the State to capitalists is not consequence of the dependency on private capital, but it results from the presence of certain classes or fractions of classes at state institutions. Thus, the concept of permeability means that the state is more open to some interests because there are classes or fractions of classes that defend them within State agencies and government bodies. The concepts of "permeability" and "selectivity" help to understand issues related to differences of political influence, since both may be used to analyze the access of interest groups to political institutions. In the end, "permeability" and "selectivity" refer to the same phenomenon: the openness of the state to economically privileged groups. The general idea 
of both concepts is that state institutions are more open to economically privileged groups. I use the term "capillarity" to discuss this "openness", which may be the result of either the permeability or the selectivity of state institutions.

Accordingly, it is possible to question what groups have more opportunities to orientate state's decisions and what variables affect this differential capillarity. Following the Marxist premises, classes and fractions of dominant classes would have privileged access to state's decisions through interest groups, since they have the necessary economic resources to maintain the activities of this type of political organization. As Santos (2007: 283) explains, the class structure implies also differences of associative habits. Whereas the capital has three different forms of collective action - the enterprise, the informal cooperation and the association - workers have only one (the trade union).

It is not different in the creative industries, although artists and creators take other forms of collective action in addition to trade unions. Agents with more economic resources have more means to participate in politics. Therefore, they also have more chances to be listened by the government. Thus, copyright reform will probably favor secondary right holders ${ }^{14}$ or famous primary right holders. This does not mean that "they will always win", but they have more opportunities to contact political authorities or to affect the public opinion and, consequently, to orientate public policies on copyright and related rights.

\section{Final Remarks}

The main goal of this article was not to provide conclusions, but to shed a light on how Marxist perspectives can analyze copyright. I do not claim Marxism is the only way or even the best way

14. A practical example is provided by the discussions regarding the copyright reform in the European Union. Although it started with a focus on positive rights to users, the limitations and exceptions provided were too restrict. The proposal of the directive also included a new related right for press publishers. Nevertheless, it is important to remember that other types of resources available to other agents, such as the Internet, may balance the economic power of some stakeholders. Collective action gains new cheaper opportunities with these new technologies and this may be of particular relevance in the field of copyright and related rights (see Herman 2009). to analyze copyright and related rights, but I argue that it can provide useful tools to a research agenda focused on issues related to inequality and economic resources in the field of intellectual property, especially considering its linkage to capitalism. Since the current system of copyright protection emerged with capitalism, it may be subject to criticisms from Marxism.

It is not that all systems of copyright protection are unnecessary or negative, but Marxism points out to problems related to the adoption of a bourgeois concept of private property. The actual functioning of copyright law benefits secondary right holders, especially big companies, instead of author and creators, despite the emphasis they receive in intellectual property theories. A research agenda on Marxism and copyright would focus primarily on the historical process and class formation in addition to the debate about the appropriation of the social product by the different stakeholders that take part in disputes concerning copyright.

There are many elements in creative industries that are related to core discussions within Marxist theories. Marx's (1970 [1867]) theory of value, for instance, brings an interesting debate about productive relations between different agents. His thoughts on the circulation of capital, understood as a social relation, may be also useful. However, due to page restrictions, this paper does not provide a full account of all the concepts and discussions provided by Marxism. Such a comprehensive account is not even possible, as Marxist theories comprise many authors and perspectives.

The core concepts approached in this paper were "class", "exploitation", and "field". The concept of "field" comes from the field theory developed by Pierre Bourdieu (1986), who argues the law reflects the current balance of powers. A research agenda on these items would try to analyze the historical process regarding the stakeholders involved in the field of copyright and related rights. By using methods such as process tracing, it is possible to study historical data about publishing business and the relationship between artists, publishers and record labels over a longer period. It is also possible to study the influence of these agents in the development of copyright laws through the analysis of documents concerning 
draft bills and public speeches. A varied range of methods and technics may be used in this regard.

Whereas Marxism may provide some important tools to understand the relationship between stakeholders that participate in the debate on copyright public policies, this research subject can also aid to improve Marxist theories. Studying how stakeholders with different backgrounds and social origins affect State institutions may help to develop a more adequate class framework. This type of analysis also points to the relevance of differences infraclasses. It shows right holders are not a homogeneous class with same economic resources. On the contrary, the expression "right holder" comprises from the independent and unknown author to the most recognized artists and major record labels. These differences must be considered because different right holders have distinct impacts on politics.

Thus, studying lobbying in the creative industries may help to identify the different classes and fractions of classes involved in pressuring the state for specific policies regarding copyright and related rights. Observing some elements related to class theory - as authority, income, etc. (Wright 1997) - may aid to develop an updated framework on classes in the modern society. Although some resources may balance economic possession, Marxism claims economic variables such as class and income are still important. It is not that class explains everything, but it is still an important tool to understand some contemporary phenomena (see Wright 1997).

As the discussion on the concept of intellectual elites shows, the classical dichotomy between proletariat and property owners does not prevail as some middle classes emerged since the end of the industrial revolutions. Therefore, there are complex relationships between different agents occupying economic positions in modern society. Nevertheless, the conflict between labor and capital is still relevant insofar as exploitation exists and portrays an important role in the contemporary capitalism.

Finally, studying lobbying in the creative industries is important to the cultural field also. This proves to be a special issue to society and the academic community, because it is related to questions about concentration of cultural goods in the hands of big companies, such as famous publishers and major record labels. Therefore, studies on how concentration of this content in big companies may hinder cultural diversity and freedom of expression must be encouraged.

\section{Acknowledgment}

The author would like to offer her special thanks to Marcos Souza, Samuel Barichello and José Vaz for triggering her interest in studying the field of copyright and related rights.

\section{References}

[1] Bosselman, M. 2006. Understanding Creative Industries: Cultural statistics for public-policy making. Unesco.

[2] Bourdieu, Pierre. 1986. O poder simbólico. Lisbon: Difel.

[3] Bourdieu, Pierre. 2011. "O Campo Político." Revista Brasileira de Ciência Política 5: 193-216.

[4] Bottomore, Thomas B. 1966 [1964]. Elites and Society. Penguin Books: London.

[5] Boyle, James. 2008. The Public Domain: Enclosing the Commons of the Mind. New Haven and London: Yale University Press.

[6] Dunlop, Steward, and Susan Galloway. 2006. "Deconstructing the Concept of "Creative Industries'". In Cultural Industries: The British Experience in International Perspective, edited by Christiane Eisenberg, Rita Gerlach, and Christian Handke. Ebook: http://edoc.hu-berlin.de (last accessed March 22, 2017)

[7] Hebb, Marian, and Warren Sheffer. 2006. "Towards a Fair Deal: Contracts and Canadian Creators' Rights". Prepared for the Creators' Copyright Coalition and the Creators' Rights Alliance/Alliance pour les droits des Créateurs. http://www.creatorscopyright.ca/ documents/hebb-sheffer/contracts-study-introduction. html\#introduction (last accessed March 22, 2017).

[8] Herman, Bill D. 2009. "The battle over digital rights management: A multi-method study of the politics of copyright management technologies". PhD dissertation, University of Pennsylvania.

[9] Hughes, Justin. 1988. "The Philosophy of Intellectual Property." Georgetown Law Journal 77(287).

[10] Hull, Gordon. 2009. "Clearing the Rubbish: Locke, the Waste Proviso, and the Moral Justification of Intellectual Property." Public Affairs Quarterly 23(1): 67-93.

[11] Fisher, William T. 2001. "Theories of Intellectual Property". In New Essays in the Legal and Political Theory of Property, 193.

[12] Fisher, William T. 2004. Promises to Keep: Technology, Law, and the Future of Entertainment. Stanford: Stanford University Press.

[13] Landes, William M., and Richard A. Posner. 1989. "An Economic Analysis of Copyright Law." Journal of Legal Studies 18: 325-363.

[14] Larivière, Vincent, Stefanie Haustein, and Philippe Mongeon. 2015. "The Oligopoly of Academic Publishers in the Digital Era." PLOS ONE 10(6).

[15] Lee, David. 2013. Creative Labour in the Cultural Industries. Sociopedia.isa. 
[16] Littoz-Monnet, Annabelle. 2006. "Copyright in the EU: droit d'auteur or right to copy?." Journal of European Public Policy 13(3): 348-455.

[17] Marx, Karl, and Friedrich Engels. 2007 [1848]. Manifesto do Partido Comunista. São Paulo: Martin Claret.

[18] Marx, Karl. 2005 [1844]. A Questão Judaica. São Paulo: Centauro.

[19] Marx, Karl. 1970 [1865]. Salaire, prix et profit. Beijing: Éditions en Langues Etrangères.

[20] Marx, Karl. 1981 [1875]. Critique des programmes de Gotha et d'Erfurt. Paris: Sociales.

[21] Marx, Karl, and Friedrich Engels. 1970 [1867]. Capital: a critical analysis of capitalist production. Moscow: Progress.

[22] McGuigan, Glenn S., and Robert D. Russel. 2008. "The Business of Academic Publishing: A Strategic Analysis of the Academic Journal Publishing Industry and its Impact on the Future of Scholarly Publishing." Electronic Journal of Academic and Special Librarianship 9(3).

[23] Menell, Peter S. 2000. "Intellectual Property: General Theories". In Encyclopedia of Law Economics. Edward Elgar Publishing.

[24] Miguel, Luis Felipe. 1998. "De que falam os marxistas quando falam em classes?." Revista Mediações Londrina 3(1): 23-29.

[25] Narveson, Jan. 1999. "Property Rights: Original Acquisition and Lockean Provisos." Public Affairs Quarterly 13(3): 205-227.

[26] Offe, Claus. 1984 [1972]. Problemas estruturais do Estado capitalista. Rio de Janeiro: Tempo Brasileiro.

[27] O'Hara, Dan. 2000. "Capitalism and Culture: Bourdieu's Field Theory." Amerikastudien/American Studies 45(1): 4353.

[28] O'Rourke, Maureen A. 2003. "Bargaining in the Shadow of Copyright Law after Tasini." Case Western Reserve Law Review 53(3): 605-638.

[29] Pires, Bruno Teixeira Bento. 2012. "The impact of 'Creative Industries' definitions on subsector typologies. School of Arts of the Catholic University of Portugal". Master dissertation, School of Arts of the Catholic University of Portugal.

[30] Poulantzas, Nicos. 2000 [1978]. O Estado, o poder, o socialismo. Rio de Janeiro: Edições Graal.

[31] Rossiter, Ned. 2003. FCJ-001 Report: "Creative Labour and the Role of Intellectual Property." The Fibreculture Journal 1.

[32] Santos, Luiz Alberto. 2007. "Regulamentação das atividades de lobby e seu impacto sobre as relações entre políticos, burocratas e grupos de interesse no ciclo de políticas públicas - análise comparativa dos Estados Unidos e Brasil", PhD dissertation, University of Brasília.

[33] Söderberg, Johan. 2002. "Copyleft vs. Copyright: A Marxist critique." First Monday 7(3).

[34] Thompson, Edward Palmer. 1978. "Eighteenth-Century English Society: Class Struggle without Class?" Social History $3(2)$.

[35] Wright, Erik Olin. 1997. "Class Analysis". In Class Counts: Comparative Studies in Class Analysis. Cambridge: Cambridge University Press.

[36] Vico, Antonio Muñoz. 2015. "Praise and criticism of the collective management of copyrights: a Spanish and European view." International Journal of Intellectual Property Management $8(1 / 2)$.

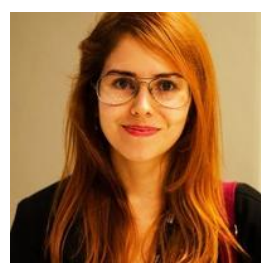

Nayara Albrecht earned her master's degree in Political Science at University of Brasília in 2015. PhD candidate at the same institution. Works at the Ministry of Culture of Brazil since 2014. As Legal and Foreign Affairs Officer at the Department of Intellectual Rights, has coordinated the staff responsible for dealing with international negotiations and regulatory issues on copyright and re-

lated rights. Member of the research group "Democracy and Inequalities" (Demodê) at University of Brasília, has dedicated all her academic life to study and understand issues related to the functioning of democracy. Has vast experience in Political Science and its intersection with Law, focusing on political theory and philosophy of law. Has been studying the following subjects: democracy (democratic theory), inequality, theories of justice, international affairs, theories of State and intellectual property rights.

Photo (Daniela Duarte 